\title{
From post-communist democratic laissez-faire to prevention of territorial fragmentation: tightening the rules of municipal splits in Central and Eastern Europe after 1990
}

\begin{abstract}
The article discusses municipal boundary changes in Central and Eastern Europe, concentrating on the heavily under-researched phenomenon of municipal splits. The first part describes the basic facts of municipal secessions in the region analysed. The second part presents a model explaining the national and municipal level factors behind the variation in the occurrence of successful split initiatives. It distinguishes between national institutional settings, economic, identity (cultural) and local political factors.
\end{abstract}

Keywords

Territorial reforms $\bullet$ local government $\bullet$ economy of scale $\bullet$ local democracy Central and Eastern Europe

๑) University of Warsaw - Faculty of Geography and Regional Studies

\author{
Paweł Swianiewicz \\ Department of Local Development and Policy, \\ Faculty of Geography and Regional Studies, \\ University of Warsaw, Poland \\ e-mail: pswian@uw.edu.pl \\ Received: 6 May 2020 \\ Accepted: 10 December 2020
}

Introduction

Territorial-administrative reorganisations have attracted a lot of attention from scholars of various social sciences, including political science, political geography, public administration studies and economics. The importance of the topic in Europe is strengthened by the numerous territorial reforms, usually an amalgamation of smaller local government units, implemented in various countries over the last two decades. These types of reforms have been the subject of numerous studies (e.g. Baldersheim \& Rose 2010; Swianiewicz 2010, 2018). Their consequences have been heavily researched, even if academics still have not reached a consensus on the impact of amalgamation on costs, the capacity to deliver services, or on local democracy. There are several recent publications on those issues, in the form of meta-analysis of individual empirical studies, which allow for the drawing of general conclusions (see e.g., Chatry \& Hulbert 2017; Drew et al 2019; Ebinger et al 2019; Gendźwił et al 2020; Tavares 2018; McDonnell 2019).

But in this article, we focus on the opposite phenomenon: municipal territorial fragmentation. That type of territorial change is almost entirely overlooked by mainstream academic literature. An extensive review of international academic journals identified several hundred empirical studies of amalgamation reforms and their consequences, but less than a dozen studies about municipal splits. A few of these address the causes and process of splits in Sweden (Erlingsson 2005; Brink 2004) and Canada (Tanguay \& Wihry 2008). Four others look at the impact of splits on the economic and democratic performance of newly-created local government units (see Dollery et al 2011 as well as Drew \& Dollery 2014 on Australia; Lima et al 2019 on Brazil; Swianiewicz \& Łukomska 2019 on Poland)

Why are municipal divorces so under-researched compared to municipal amalgamations? There might be two major reasons. One is that municipal splits are usually not the result of a conscious central government policy, but rather occur as the result of bottom-up pressure from local political elites and communities. Therefore, scholars interested in analysis of the impact of government policies tend to concentrate on merger reforms rather than on municipal divorces which are results of singular, dispersed, bottom-up initiatives, and not of policy programmes. The second potential reason is geographical location. Merger reforms have often been introduced in countries which are close to the core of academic research (Maisonobe et al 2017). At the same time, one may note that the vast majority of changes in the other direction, leading to territorial fragmentation of the municipal systems, have taken place in Central and Eastern Europe, which is closer to semi-periphery of the production of social science knowledge ${ }^{1}$, and therefore the topic is, to a lesser extent, covered by the mainstream journals and scholars from the core of the academic world.

In this article, and through this issue of the journal, we want to contribute towards closing that gap in the knowledge. This article has two main goals, reflected in separate sections. The first one is descriptive: to provide a general picture of the scale (number) of municipal splits leading to the creation of new local government units and to show the most typical patterns of municipal splits. As we argue in the next section, the phenomenon of municipal territorial fragmentation has largely been concentrated in Central and Eastern Europe, and therefore we focus our attention on this part of the continent. The second goal is to discuss the factors which lie behind the successful secession initiatives. Available data do not allow us to identify all formalised attempts to split municipalities, so we have decided to focus only on those initiatives which were successful, i.e., which eventually achieved the goal (split) formulated by their initiators. The main hypothesis which is verified in this section is that the relationship between the institutional setting, the legal framework and the central government's policies on municipal boundary reforms is the

${ }^{1}$ See Swianiewicz \& Kurniewicz 2019 for an analysis of the place of Central and Eastern Europe in a local government studies' map of knowledge production 
most important factor in explaining the number of successful splits of local governments. But we also discuss the loca factors which influence the likelihood of local secessions. The starting point for this part of the article is the model developed by Erlingsson (2005) in his discussion of Swedish changes of municipal organization. However, the Erlingsson model has been rebuilt in such a way to fit the realm of sub-national politics of Central and Eastern Europe; which differs significantly, in many respects, from the Swedish (or more broadly speaking Nordic) environment. The Erlingsson model has been extended to discuss the national institutional setting in a more detailed way. Erlingsson addresses two questions: why secession initiatives arise and if they do, what factors increase the likelihood of their successful implementation. This article focuses only on those initiatives which were successfully completed.

Several examples suggest that split initiatives are often a delayed reaction to amalgamation reform. This phenomenon has been observed not only in Central and Eastern Europe in early $1990^{\text {th }}$ (as we discuss later), but also as a follow-up to Swedish (Brink 2004), Australian (Drew \& Dollery 2014), or Canadian (Tabguay \& Wihry 2008) amalgamation reforms. Some of the studies (e.g., Brink 2004 describing a hunger strike in the town of Dorothea in the protest against forced amalgamation) expose the false myth of consensual amalgamation reforms in Western democracies. If so, understanding the nature and consequences of splits is also important for policy-makers working on territorial consolidation programmes.

The empirical material used in this article relies on the following sources:

- Data on changes in the number of municipal governments in 39 European countries in the period 1990-2014 (see Ladner et al 2019);

Information concerning the evolution of the legal framework for municipal boundary changes provided by experts ${ }^{2}$ from 9 countries of Central and Eastern Europe;

- A database of 535 municipal splits which occurred in 10 countries $^{3}$ of Central and Eastern Europe in the period 19952018. The database includes information on the year of the secession and the population size of the old and newlyemerging local governments.

Before we turn to the empirical data, it is useful to discuss briefly the terminology associated with the type of territorial changes in our focus. In the sparse literature on municipal territorial fragmentation different terms are used to describe the phenomenon: some authors write about de-amalgamation (e.g., Dollery et al 2011), de-merger (Tanguay \& Wihry 2008), while others use the term municipal divorce (e.g. Swianiewicz et al. 2018), secession (e.g. Erlingsson 2005; Lima et al 2019), or splits (e.g. Swianiewicz \& Łukomska 2019). The first three terms suggest that the processes researched might be a reverse reaction to earlier, amalgamation (merger) reforms. As discussed later in the article, a reaction such as this might be considered among the important factors

${ }^{2}$ Between December 2018 and March 2019, the experts answered a survey consisting of several open questions (in the form of mini-essays) concerning various aspects of municipal splits. The responses to the questions on national legal framework are used in this article. The survey was answered by experienced academics - experts in local government studies in the respective countries: Desislava Kalcheva fo Bulgaria, Dubravka Alibegović for Croatia, Lucie Sedmihradská for Czech Republic Gabor Dobos for Hungary, Jurga Bučaitè-Vilkè for Lithuania, the author of this article for Poland, Cristina Stanuş for Romania, Ján Buček for Slovakia and Irena Bačlija for Slovenia.

${ }^{3}$ The list of countries covered by this detailed analysis includes: Bulgaria, Croatia, Czech Republic, Hungary, Lithuania, Montenegro, Poland, Romania, Slovakia and Slovenia and (apart from Montenegro) the data was collected by the same experts answering the survey (except for Croatia, where the database was compiled by Mihovil Škarica). Unfortunately, attempts to find comparably detailed information on municipal splits in Bosnia and Herzegovina have failed. explaining the reasons behind territorial fragmentation. The other terms (secession, split etc.) sound more neutral in this respect, since they do not pre-assume any reaction to earlier events. In this article we do not prefer any of those terms, which are sometimes used interchangeably.

\section{Municipal splits in Europe after 1990 - basic facts}

The map of municipal local governments in Europe has been very far from stable over the last 30 years. Most of the changes have been going in the direction of territorial consolidation through municipal amalgamations. Even if we limit the time horizon to the first two decades of the $21^{\text {st }}$ century, such reforms - implemented either as a one-step reform or in a more incremental way over several years - can be identified in at least 19 European countries. As a result, the total number of municipalities in Europe has been systematically shrinking.

Yet at the same time, the opposite phenomenon - cases of municipalities splitting - were identified in several countries as well. In the "old Europe" (the EU 15 member states and other countries of Western Europe), splits were very rare. In the last decade of the $20^{\text {th }}$ century, the number of secessions reached $2 \%$ of the total number of municipalities in both Austria ${ }^{4}$ and Sweden, only $1 \%$ in Portugal and just single cases in Italy, Spain and four of the German landers. Since 2000, there have been even fewer splits - just a handful of cases in Spain and in the German landers of Bayern and Hessen.

The intensity of municipal secessions in Central and Eastern Europe stands in sharp contrast to the changes in Western Europe; in some countries the number of splits was as high as several hundred, and in some of them the total number of local governments has more than doubled. Altogether, the data in table 1 , which covers 13 countries of the region, show over 5,000 cases of splits. One can add to this number several, similar cases in Ukraine (over 150), for which we were unable to collect precise information.

As is shown in table 1, the vast majority of splits took place during the first few years of political transformation. Very often they were interpreted as a reaction to the compulsory, undemocratic merger reforms that had been imposed by the communist regimes in previous decades (IIIner 2010; Baldersheim \& Rose 2010; Swianiewicz 2010). The political watershed of 19891990 enabled "supressed" local communities to regain their own, autonomous local governments. Therefore, that first wave of secessions is relatively easy to interpret and is covered by the existing academic literature. But also, in the following years, individual cases of municipal splits have been quite common in several countries in the eastern part of the continent. There have also been cases of voluntary mergers (e.g., Musilova \& Heřmánek 2015 on the Czech Republic) but these were less common than secession initiatives. These "second wave" territorial changes introduced within the last 25 years are the focus of the following sections of this article.

In the years following the political changes of 1990, the number of successful secession initiatives has been gradually decreasing. If we exclude the atypical cases of Moldova (the reversal of failed amalgamation reforms) and Romania (see section 2.1 of this article for explanation) the, there were more than 300 splits during the second half of the 1990s, but this fell to only 67 in the first half of the 2000s and a mere 14 in the 2010s. An especially sharp drop was seen during the last decade, when there were only single cases of municipal splits (and in none of the countries was the number higher than four). The reasons for this change will be discussed in section 2.1 of this article.

${ }^{4}$ Such cases were more common in two of Austrian lands - Burgenland where number of municipalities between 1990 and 200 has increased by $18 \%$, and in Karnten where it grew by $9 \%$ 
Table 1. Number of municipal splits in Central and Eastern Europe

\begin{tabular}{|c|c|c|c|c|c|}
\hline & \multirow{2}{*}{$\begin{array}{c}\text { Number of } \\
\text { municipalities in } 1990\end{array}$} & \multicolumn{4}{|c|}{ Number of newly-established municipalities in $\left(^{*}\right)$ : } \\
\hline & & $1990-1994(* *)$ & $1995-2000$ & 2001-2009 & 2010-2018 \\
\hline Bosnia and Herzegovina & 109 & 0 & $33(30.3 \%)$ & 0 & 0 \\
\hline Bulgaria & 274 & 0 & $6(2.2 \%)$ & $2(0.6 \%)$ & $1(0.3 \%)$ \\
\hline Croatia & 116 & $372(321 \%)$ & $69(59.5 \%)$ & $10(8.6 \%)$ & 0 \\
\hline Czech Republic & 4100 & $2130(52 \%)$ & $25(0.6 \%)$ & $11(0.3 \%)$ & $4(0.1 \%)$ \\
\hline Hungary & 1586 & $1563(98.5 \%)$ & $9(0.6 \%)$ & $18(1.1 \%)$ & $3(0.2 \%)$ \\
\hline Lithuania & 58 & 0 & $2(3.4 \%)$ & 0 & 0 \\
\hline Macedonia & 34 & 0 & $89(262 \%)$ & 0 & 0 \\
\hline Moldova" & 959 & 0 & 0 & $249(26.0 \%)$ & 0 \\
\hline Montenegro & 21 & 0 & 0 & 0 & $2(9.5 \%)$ \\
\hline Poland & 2383 & $96(4.0 \%)$ & $21(0.9 \%)$ & 0 & $1(0 / 1 \%)$ \\
\hline Romania & 2948 & $2(0.1 \%)$ & $5(0.2 \%)$ & $229(7.8 \%)$ & $1(0.1 \%)$ \\
\hline Slovakia & 2669 & 196 (7.3\% & $44(1.6 \%)$ & $8(0.2 \%)$ & 0 \\
\hline Slovenia & 62 & $85(137 \%)$ & $45(72.6 \%)$ & $18(29.0 \%)$ & $2(3.2 \%)$ \\
\hline Total & 15319 & 4444 & 348 & 545 & 14 \\
\hline
\end{tabular}

$\left(^{*}\right)$ in brackets - number expressed as percentage of the initial number of municipalities in 1990

$\left({ }^{*}\right)$ figures for 1990-1994 are not very precise, since they are estimations based on changes in numbers of municipal governments. Source: own elaboration

\# The case of Moldova is very specific. In 1999 there was an amalgamation reform reducing the number of municipalities from 959 to 649. But this reform was considered unsuccessful and was almost totally reversed in 2003 when the number increased again to 898. Technically speaking it meant over 200 splits concentrated in one year. And it was perhaps the only known case from Europe in which splits were not the result of bottom-up pressures exerted in individual cases, but rather of a change in state-level policies. Because of this untypical character, we exclude the case of Moldova from further analysis.

What are the new municipalities, which emerged from the divorces implemented since 1995, like? On the basis of the data collected, we may say that, first of all, the newly-created municipalities vary strongly in terms of their population size. The Czech Republic and Lithuania provide two opposite extremes. In the Czech Republic over three quarters of the new municipalities are extremely small, with populations of below 1,000. Slovakia and Hungary follow a similar model, although in the latter case, the size of the new territorial units is more diversified. At the same time, the new local government units created in Lithuania (and to a lesser extent in Bulgaria) are relatively big; inhabited by several thousand people each. The most diversified in size are the new units in Croatia, Slovenia and Poland. Obviously, the size of new local governments should be related to the model of territorial organization in a country.

Definitely, the main reason to split is not that the municipality was "too big" before the split. The data in table 2 suggests there is no simple relationship to indicate that splits are more frequent in countries with big municipalities. It is rather the opposite phenomenon; secessions are more frequent in territoriallyfragmented countries than in territorially-consolidated ones.

Moreover, in several countries, those municipalities which are the subject of a split were often smaller than the national mean population size (Romania, Croatia, Poland, Montenegro and, to some extent also, Slovenia). Even more telling is that nearly all of the newly-created local government units were smaller than the national mean, and usually even smaller than the national median population size (in the latter case the only exception is for the Czech Republic, but the median size was extremely low there).

Taking into account the relative size of two "divorcing" municipalities, we may build the following typology:

- "even-stevens" - where two municipalities are relatively similar in terms of population size. Normally, this concerns rural areas with a local government unit consisting of two or more settlement s (typically villages), and with two centres of gravitation of similar strength. In our calculations this type is operationalized by the "abandoned municipality" being no more than twice as big as the leaving partner;

- " "nestling flying the nest"- a very small, new, local government breaks away from the much larger partner (in this case at least five times bigger). There might be two variants of such a situation: the first, where the peripheral (suburban) district secedes from a much larger city, and the second, where a distant, small village separates from a larger one consisting of several settlement units of rural local government;

- "young grown-ups leaving the nest" - where a smaller partner breaks from the larger, but the size difference is not so dramatic (in our definition: between 2 and 5 times bigger). 
MISCELLANEA GEOGRAPHICA - REGIONAL STUDIES ON DEVELOPMENT

Vol. 25 • No. 1 • 2021 • pp. 5-17 • ISSN: 2084-6118 • DOI: 10.2478/mgrsd-2020-0046

Table 2. Municipal splits and size of local governments

\begin{tabular}{|c|c|c|c|c|c|c|c|}
\hline & \multirow{2}{*}{$\begin{array}{l}\text { Number of } \\
\text { splits since } \\
1995\end{array}$} & \multirow{2}{*}{$\begin{array}{l}\text { Mean } \\
\text { population } \\
\text { size }\end{array}$} & \multirow{2}{*}{$\begin{array}{l}\text { Median } \\
\text { population } \\
\text { size }\end{array}$} & \multicolumn{2}{|c|}{$\begin{array}{l}\% \text { of "pre-split" } \\
\text { municipalities which were } \\
\text { smaller than: }\end{array}$} & \multicolumn{2}{|c|}{$\begin{array}{c}\% \text { of new "post-split" } \\
\text { municipalities which are } \\
\text { smaller than: }\end{array}$} \\
\hline & & & & mean & median & mean & median \\
\hline Bulgaria & 9 & 32105 & 15087 & 29 & 0 & 100 & 100 \\
\hline Croatia & 79 & 8127 & 3335 & 69 & 18 & 97 & 91 \\
\hline Czech Rep. & 40 & 1787 & 416 & 23 & 3 & 95 & 28 \\
\hline Hungary & 30 & 3217 & 888 & 13 & 0 & 90 & 57 \\
\hline Lithuania & 5 & 47465 & 28342 & 0 & 0 & 100 & 80 \\
\hline Montenegro & 2 & 29581 & 19451 & 50 & 50 & 100 & 100 \\
\hline Poland & 22 & 16201 & 7515 & 68 & 21 & 89 & 84 \\
\hline Romania & 235 & 7032 & 3604 & 78 & 14 & 100 & 97 \\
\hline Slovakia & 52 & 1868 & 638 & 19 & 3 & 100 & 55 \\
\hline Slovenia & 65 & 10367 & 5106 & 35 & 15 & 100 & 91 \\
\hline
\end{tabular}

Source: own elaboration

As a rule, the part of the municipality which initiates the secession is the smaller partner, which wants to break from the "bigger brother". However, there are also exceptions to this rule, in which it is the larger partner who wants to divorce from the smaller part of the municipality. Such a situation could be described as a fourth type of split - "Bob the bully" - in which the larger part wants to get rid of an annoying part of the municipality. Unfortunately, information about the initiators of each of type of split is far from complete, and we are not able to distinguish that fourth type. From the incomplete data collected, we know only that cases where the "initiator" is larger than the "abandoned" municipality are relatively rare and constitute less than $10 \%$ of all collected cases. Such situations happen relatively more frequently in Romania and Poland although, even in those countries, they only represent a tiny minority of all the cases studied.

If we consider all the analysed cases, all three types are almost equally common. But if we exclude the very untypical case of Romania (see figs. 1 and 2), almost $60 \%$ of cases are where the size of the unit which has initiated the split is much smaller than the remaining part of the former municipality (i.e., "nestling flying the nest" type). Less than $15 \%$ of all cases belong to the "even-stevens" category. But this differs greatly between analysed countries. In the Czech Republic (and to a smaller extent also in Slovakia and Hungary), the dominant model is the splitting-off of a very small part of a much larger town. In the majority of cases in those countries, the population size difference between the initiator and the abandoned municipality is more than 10 times. The most extreme case of all is the secession of a tiny district named Ostrata (of just over 300 people) from the city of Zlín (Czech Republic) with a population of over 80,000 in 2001; so the seceding municipality was over 230 times smaller than the abandoned partner. But similar cases may be found also in Hungary (in 2002 a small district broke away from the city of Eger with a population of over 55,000 , and the seceding part was over 160 times smaller than the bigger partner) and in Slovakia (in 2002 a district almost 150 times smaller broke away from the city of Nitra with a population of over 80,000 ). A similar case, of a small district breaking from a much larger city, took a place in
1999 in Slovenia (the secession of Miklavž na Dravskem Polju from the city of Maribor), but this time the size difference was "only" just over 20 times. In the remaining countries, the analysed cases are either more diversified in this respect (Slovenia, Poland, Bulgaria), or the size of both parties in the split is more balanced (Lithuania, Montenegro, Romania).

There is also a visible trend when we compare "early" and "late" split cases. In most countries (Bulgaria, Croatia, Hungary, Poland, and Slovenia), the more recent splits are more often cases of the "nestling flying the nest", while, before 2000 "evenstevens" splits were more common. The opposite trend may be observed only in Romania, which has been related to their specific institutional setting at the beginning of the $21^{\text {st }}$ century, as will be explained in the discussion in the next section of the paper.

\section{Understanding municipal secession in Central and Eastern Europe}

To understand municipal secessions, we should discuss two main issues. The first is why do secession initiatives appear in particular municipalities but not in others. The second is related to the likelihood that the initiative is going to be successful. However, due to the limitations of available data, empirically we concentrate only on the initiatives which eventually successfully led to secessions. This is because we do not have information on all the initiatives formulated in this respect by local communities. But the two issues are not entirely separate, since assessment of the chances of success often helps (or discourages) the initiative to be expressed publicly.

The model identifying factors stimulating or hampering the fragmentation initiative and their implementation is summarized on the figure 3. Local governments are sub-sovereign entities, so the necessary condition for the successful split of municipalities depends on the approval of central (sometimes - especially in federal countries - regional) authorities which, in turn, are rooted in the institutional legal setting as well as the current policies of central government. The model indicates also environmental factors, which in some circumstances may produce incentives for the initiative to materialize, and political factors related to the 


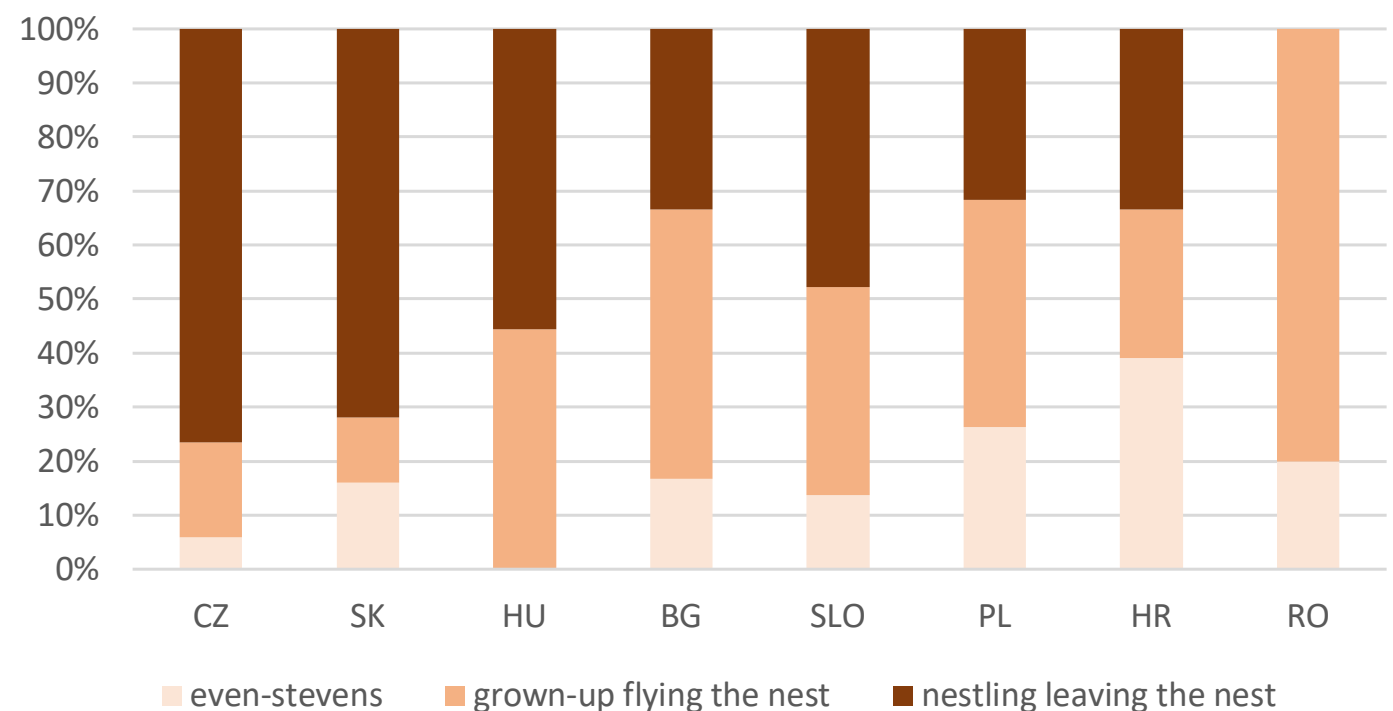

Figure 1. Typology of municipal secesions 1995-1999

Note: in this and the next figure we use following abbreviations for the countries: CZ- Czech Republic, SK- Slovakia, HU - Hungary, $B G$ - Bulgaria, SLO - Slovenia, PL - Poland, HR - Croatia, LT- Lithuania, MNG - Montenegro, RO - Romania.

Source: own elaboration

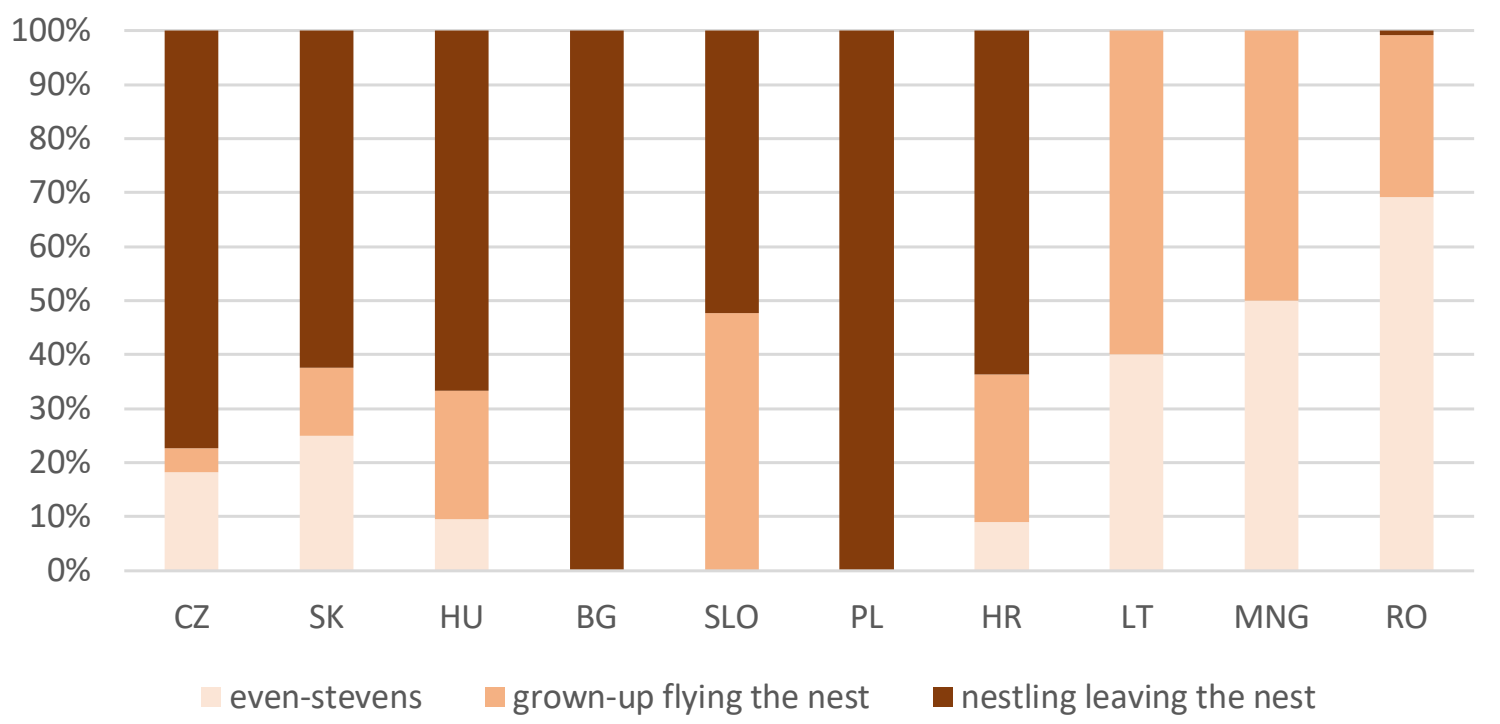

Figure 2. Typology of municipal secessions since 2000 Source: own elaboration

local political arena. The individual elements of the model and the relationship between them. One may say that the institutional setting provides country-level, while the environmental and political factors provide municipality-level factors (explanations) of local secessions.

The environmental and political factors are interlinked, so the distinction between them - although still useful - cannot be treated as very sharp. Environmental factors producing incentives for split may be modified by actors' behaviours and attitudes. In our model we assume that political actors are rational, and that their behaviour is subordinated to seeking ways to maximize political capital (driven by the chance to win the next elections).
Institutional setting - national level

The shape of national regulations concerning territorialadministrative organization has crucial importance for any split initiative. There is a variety of dimensions which are important in this respect:

- How the list of municipalities is defined in the country? The most severe restriction (both for amalgamation and for secession) is when the list is defined by the constitution. It is rare at the municipal level, but quite common at regional or other higher levels of sub-national government. A split is somehow easier, but still requires significant legislative changes, if a list of municipalities is included in the law on 


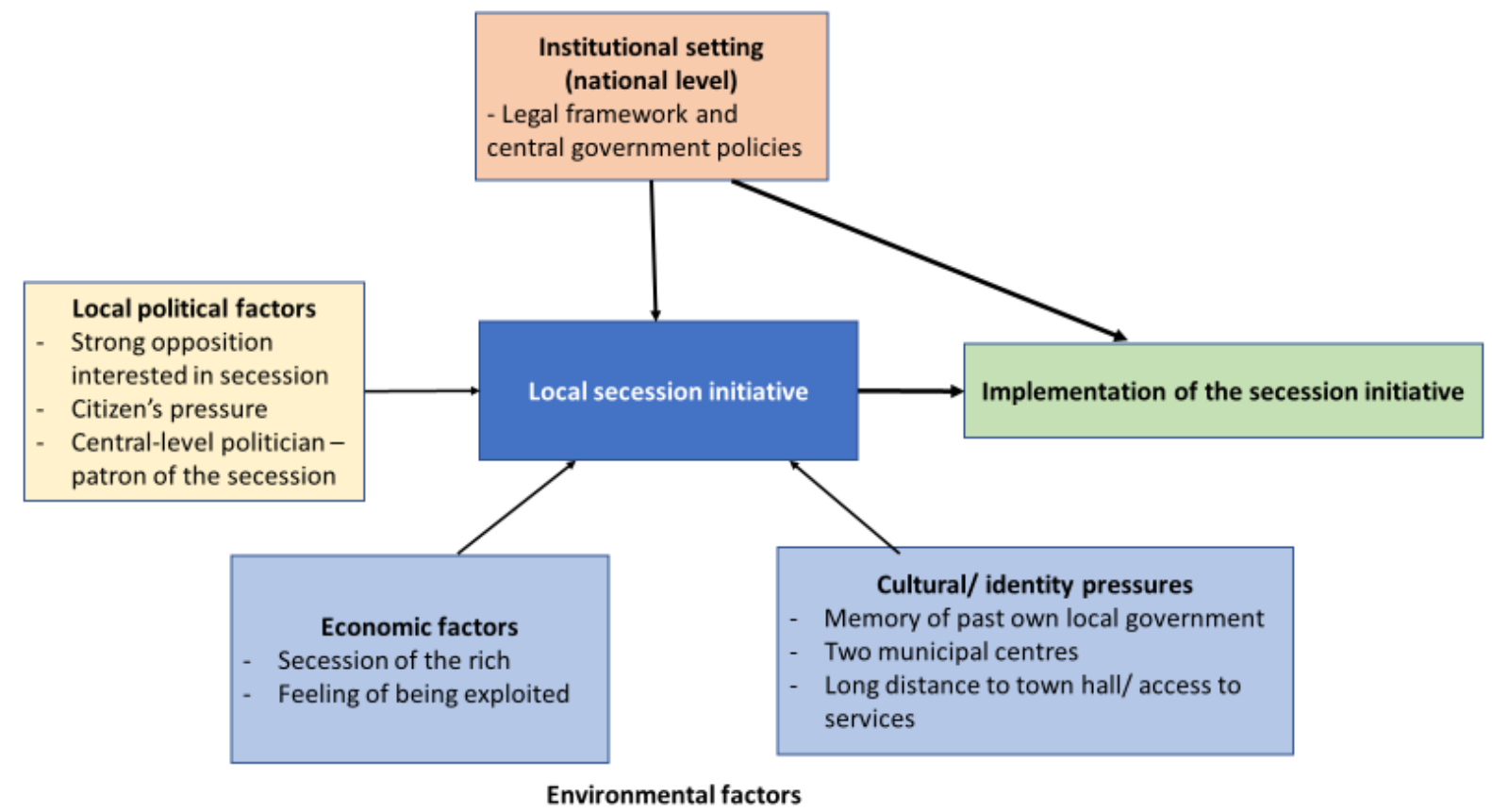

Figure 3. Factors influencing the emergence and implementation of municipal secession initiatives. Source: own elaboration

local government. But there are also countries in which the change in the number of municipal government units does not require any voting by Parliament (e.g., Poland).

- What are the regulations on the necessary and sufficient conditions of splits? In some countries, a local referendum result is binding and central government cannot oppose it (as in Hungary until 2013 reforms by the Orban government - see Dobos 2021 in this issue). But in others, there is much more discretion given to central government, who may treat a referendum (or other forms of public consultations; The European Charter of Local Government requires consultations, but does not prescribe the precise form) only as consultative (e.g., in Poland or Hungary after recent reforms).

- Who is to be asked in public consultations regarding the secession initiative? Is it the whole affected municipality, or only the citizens of the part which wants to secede? Quite often this is a grey, unregulated, area which additionally leaves discretion for those who organize consultations (usually organized, or at least supervised by central government). Depending on the desired outcome and expected opinions of citizens, the consultation process may be organized in either way.

Table 3 includes a summary of regulations and their recent changes in the countries of Central and Eastern Europe that are covered by our analysis (seven of those cases are further presented in following articles in this issue of the journal). In most of cases there is a set of minimal conditions which has to be met by a newly-created municipality. Several of them are of a character which might be open to subjective interpretation and negotiations, i.e., sufficient administrative capacity. But some of them are more precise and concrete. The most frequent is minimal population size. This is currently present in seven of the nine countries covered by Table 3 . But the solid threshold strongly varies from 1,000 (historically in the Czech Republic, Hungary and Slovakia it was even lower, at a level of 300) to 6,000 in Bulgaria and 15,000 in Lithuania. Sometimes there are also additional strict conditions (concerning, for example, the estimated level of cost or the presence of local infrastructure).

In most countries ( 6 out of 9 ) the initiative has to pass the test of a local referendum, usually with a minimal turnout threshold. It is rarely indicated in a clear way whether the referendum should include citizens of the whole affected local government area, or just the part which wants to secede. The typical practice is to ask only those parts which initiate the split. The case of Hungary is exceptional in this respect; the requirement to ask citizens of the whole old municipality (together with maintaining a high turnout validity threshold) was among the main factors limiting the number of splits after 2013.

However, in spite of the local referendum, in most of cases the final decision is still in the hands of the Central Government (or even Parliament), which may disregard the referendum results. In such circumstances, prevailing government policy plays a crucial role. In most cases, recent decades have brought a toughening of attitudes, reflected also through the imposition of more challenging formal conditions for any split initiative (see right column of Table 3). A change like this, from 1997 in Croatia to 2013 in Hungary, could be observed in at least 6 of the 9 analysed countries. The only noticeable exception is Romania, where the rules were temporarily softened (between 2002 and 2003) which provoked a very high number of secession initiatives.

The crucial importance of formal regulations, as the outcome of government attitudes towards splits, is confirmed by the data in Table 4, which illustrates the changing frequency of successful splits initiated correlated with modifications to the formal regulations. In all of the analysed cases, the impact of legislative changes is dramatically visible.

Concluding this part of the discussion, we can see three clear phases which have been repeating in several countries of 
Table 3. Formal regulations concerning municipal split initiatives in the countries of Central and Eastern Europe

\begin{tabular}{|c|c|c|c|}
\hline Country & $\begin{array}{c}\text { Conditions (thresholds) to be met } \\
\text { by new municipality }\end{array}$ & $\begin{array}{l}\text { Process of decision making on } \\
\text { secession }\end{array}$ & $\begin{array}{c}\text { Direction of changes of regulations } \\
\text { after } 1995\end{array}$ \\
\hline Bulgaria & $\begin{array}{c}\text { Minimum population size } 6,000 \\
\text { Distance to the town hall must not } \\
\text { exceed } 40 \mathrm{~km} \\
\text { Financial viability of the new } \\
\text { municipality }\end{array}$ & $\begin{array}{l}\text { Petition by } 25 \% \text { of population of the } \\
\text { part to secede } \\
\text { Legal check by regional governor } \\
\text { Local referendum } \\
\text { Final decision of Central Government } \\
\text { approved by the President }\end{array}$ & $\begin{array}{l}\text { Increased population threshold from } 4 \text { to } \\
66,000 \text { (1998) } \\
\text { Increased acceptable distance to town } \\
\text { hall from } 20 \text { to } 40 \mathrm{~km}(1998)\end{array}$ \\
\hline Croatia & No clear conditions or criteria & $\begin{array}{l}\text { Initiative of the municipal council or } \\
\text { at least } 33 \% \text { of residents of the part } \\
\text { which wants to secede } \\
\text { The secession has to be approved } \\
\text { by the Parliament }\end{array}$ & $\begin{array}{c}\text { Compulsory consultations with residents } \\
\text { in the case of a split initiated by the local } \\
\text { council (1997) and in all cases of split } \\
\text { initiatives (2006) } \\
\text { Compulsory opinion of local council and } \\
\text { county assembly (1997) } \\
\text { Compulsory approval of the Ministry of } \\
\text { Finance (1997), of the whole cabinet } \\
\text { (2006) }\end{array}$ \\
\hline $\begin{array}{l}\text { Czech } \\
\text { Rep. }\end{array}$ & Minimum population size 1,000 & $\begin{array}{c}\text { Local referendum with threshold } \\
\text { consent of } 50 \% \text { of registered } \\
\text { voters Formal approval of regional } \\
\text { government }\end{array}$ & $\begin{array}{l}\text { Increasing threshold from } 300 \text { to } 1,000 \\
\text { population }(2000)\end{array}$ \\
\hline Hungary & $\begin{array}{c}\text { Positive demographic trend } \\
\text { Infrastructure developed above } \\
\text { national average } \\
\text { Operating costs below national } \\
\text { average }\end{array}$ & $\begin{array}{c}\text { Referendum in the whole } \\
\text { municipality (not only part to secede) } \\
\text { with turn-out threshold of } 50 \% \\
\text { Minister can reject the proposal, and } \\
\text { local government may appeal to the } \\
\text { court }\end{array}$ & $\begin{array}{l}\text { Much lighter rules before } 2013 \text {. } \\
\text { Minimum population size } 300 \text { until } 2011 \\
\text { Until } 2013 \text { the referendum was } \\
\text { organized only in the part which wanted } \\
\text { to secede } \\
\text { Conditions concerning costs and } \\
\text { infrastructure introduced in } 2013\end{array}$ \\
\hline Lithuania & $\begin{array}{l}\text { Minimum population size } 15,000 \\
\text { with central settlement unit of } \\
\text { minimum } 3,000 \\
\text { Sufficient administrative capacity } \\
\text { and financial resources }\end{array}$ & $\begin{array}{l}\text { Central government initiative with } \\
\text { local consultation process } \\
\text { Formally the initiative may be } \\
\text { undertaken by local governments, } \\
\text { and the final approval requires } \\
\text { decision of the Parliament }\end{array}$ & \\
\hline Poland & \begin{tabular}{|} 
The new local government must \\
not be smaller than the smallest \\
currently existing (ca. 1,300 \\
population) and not poorer than the \\
current lowest per capita local tax \\
base. \\
Required opinion of the Ministry of \\
Finance.
\end{tabular} & $\begin{array}{l}\text { Neither the initiatives of local } \\
\text { government nor the results of } \\
\text { consultations (which may take the } \\
\text { form of a local referendum, but } \\
\text { this is not obligatory) are binding } \\
\text { for the final decision of the Central } \\
\text { Government }\end{array}$ & \\
\hline Romania & $\begin{array}{c}\text { Minimum population size } 1,500 \\
\text { Sufficient financial resources } \\
\text { Transport network from the } \\
\text { proposed municipal centre to other } \\
\text { villages } \\
\text { Sufficient social infrastructure } \\
\text { facilities (school, health care centre } \\
\text { etc.) } \\
\text { At least } 25 \% \text { population not in the } \\
\text { agriculture sector } \\
\text { More than } 45 \% \text { of houses built after } \\
1960\end{array}$ & $\begin{array}{l}\text { Application checked formally at } \\
\text { county level } \\
\text { Local referendum with turnout } \\
\text { threshold } \\
\text { Approval by Parliament requires } \\
\text { 2/3rds majority }\end{array}$ & $\begin{array}{l}\text { In } 2001-2003 \text { Central Government } \\
\text { sent proposals to the Parliament not } \\
\text { on an individual basis, but as one list } \\
\text { of all applications, which made the } \\
\text { process much smoother. This was } \\
\text { part of the } 2001 \text { government strategy } \\
\text { for public administration reform which } \\
\text { set the objective of "giving commune } \\
\text { status to } 1000 \text { villages which meet } \\
\text { the legal criteria, so as to make local } \\
\text { administration closer to the citizens". } \\
\text { The current, stricter rules were imposed } \\
\text { in } 2007\end{array}$ \\
\hline
\end{tabular}


MISCELLANEA GEOGRAPHICA - REGIONAL STUDIES ON DEVELOPMENT

Vol. $25 \cdot$ No. $1 \cdot 2021 \cdot$ pp. 5-17 • ISSN: 2084-6118 • DOI: 10.2478/mgrsd-2020-0046

Table 3. Formal regulations concerning municipal split initiatives in the countries of Central and Eastern Europe

\begin{tabular}{|c|c|c|c|}
\hline Country & $\begin{array}{l}\text { Conditions (thresholds) to be met } \\
\text { by new municipality }\end{array}$ & $\begin{array}{l}\text { Process of decision making on } \\
\text { secession }\end{array}$ & $\begin{array}{l}\text { Direction of changes of regulations } \\
\text { after } 1995\end{array}$ \\
\hline Slovakia & $\begin{array}{c}\text { Minimum population size } 3,000 \\
\text { New municipality must not have } \\
\text { infrastructure which serves the } \\
\text { whole territory of the old, pre-split } \\
\text { municipality }\end{array}$ & $\begin{array}{l}\text { Splits formally possible in election } \\
\text { years only. } \\
\text { Required referendum with } 50 \% \text { turn- } \\
\text { out threshold. } \\
\text { Agreement to secession is the } \\
\text { discretionary decision of Central } \\
\text { Government. }\end{array}$ & $\begin{array}{l}\text { Central Government stopped issuing } \\
\text { permits for splits after } 2002 \\
\text { Since } 2002 \text {, splits are formally possible } \\
\text { in election years only. A population size } \\
\text { limit was also introduced in } 2002\end{array}$ \\
\hline Slovenia & $\begin{array}{c}\text { Minimum population size } 5,000 \\
\text { Capacity to "satisfy needs of } \\
\text { citizens" }\end{array}$ & $\begin{array}{l}\text { Required referendum } \\
\text { Formal approval by the Parliament }\end{array}$ & $\begin{array}{c}\text { Before } 2010 \text { exceptions to the rule of } \\
\text { "minimum 5,000" were allowed in case } \\
\text { of justified "geographical, historical or } \\
\text { economic reasons" and the list of actors } \\
\text { who could initiate the split process was } \\
\text { longer (e.g. } 2010 \text { amendment eliminated } \\
\text { sub-municipal units from that list) }\end{array}$ \\
\hline
\end{tabular}

Source: own elaboration.

Table 4. The Average number of splits per annum before and after changes to relevant formal requirements

\begin{tabular}{|c|c|c|c|}
\hline \multirow{2}{*}{ Country } & \multirow{2}{*}{ Year of change in legislation } & \multicolumn{2}{|c|}{ Average number of splits per annum } \\
\cline { 3 - 4 } & & Before the change & After the change \\
\hline Bulgaria & 1998 & 1 & 0.1 \\
\hline Croatia & 1997,2006 & 15.8 & 1.9 after 1997,0 after 2006 \\
\hline Czech Republic & 2000,2003 & 3.8 & 2.7 after 2000 and 0.5 after 2008 \\
\hline Hungary & 2013 & 1.5 & 0.2 \\
\hline Romania & $2001-2003\left(^{*}\right), 2007$ & 47.3 & 2.3 and 0.5 after further tightening of the \\
procedure in 2007
\end{tabular}

${ }^{*}$ ) in Romania the period of softened regulations (2001-2003, but with the peak of splits effective in 2004) is compared with years before and after this period.

Note: Lithuania and Poland are omitted from the table since there have been no significant modifications to the rules related to municipal splits.

Source: own elaboration.

Central and Eastern Europe. The first was related to the very start of their democratic transformation and decentralization. The number of municipalities rapidly increased, due to the process of reversing the compulsory mergers made under the communist regime. The central governments did not interfere very much with this process, considering blocking of de-amalgamation as a violation of democracy and local autonomy. This phase had an obvious endogenous (related to post-communist transition) character, but at the same time it had support in the more general trend in Europe. Erlingsson et. al. (2015) note that, at the beginning of the 1990s, it was a commonly-held view that the era of large administrative structural reforms was over (see also Marcou 1993), and that the trend was rather the reverse. In Sweden, the CentreRight government that won the election in 1991, declared a favourable stance towards municipal secessions, i.e., a desire to move back to smaller (and greater numbers of) geographical units. But the dominant trend soon changed again in favour of territorial amalgamations.

In the second phase, which might be roughly dated from the second half of the 1990s and the first years of the $21^{\text {st }}$ century, there is a gradual saturation of natural demand for further deamalgamations. The number of secession initiatives drops, but legal regulations are still very liberal in this respect, and they do not create any significant barrier to the new splits. In the third phase, the perception of the negative consequences of territorial fragmentation prevails among political elites, and the formal rules become more demanding for split initiators. The new initiatives have to meet more and more challenging threshold criteria in 
order to have a chance of success. In some cases (such as Hungary or Slovakia), those new rules make new secessions practically impossible.

The evolution of the institutional framework for territorial boundary changes in Central and Eastern Europe can be also seen from the point of view of party politics. The merger reforms of the $20^{\text {th }}$ century were implemented under the communist regime. The rapid de-amalgamation was conducted under the label of decommunisation. But we know that post-communist parties had a period when they returned to power in most of the countries in the region. So, one may ask, whether the hardening of the rules for secessions was introduced by those parties. Maybe they want to stop the deconstruction of the territorial system implemented by their predecessors under the old political regime? An additional argument strengthening this hypothesis might be the observation of Erlingsson (2005), that left-wing parties were traditionally more in favour of territorial consolidation, while right-wing parties would allow for larger fragmentation of the municipal system. But this logic does not seem to work in Central and Eastern Europe. In Bulgaria the change of rules in 1998 was introduced by Ivan Kostov's government of the Union of Democratic Forces, which was a union of several, smaller anti-communist organizations. In Slovakia, the 2002 halt to splits was initiated by the centreright-wing government of Mikuláš Dzurinda. In Hungary, the 2013 change of regulations was introduced by right-wing FIDESZ. Moreover, in Romania the short window for "easy secessions" was open by the post-communist government of Adrian Năstase's Social Democratic Party. Stanuş (2021, in this issue) argues that supporting territorial fragmentation was one of the ways to prove the democratic credentials of the post-communist party, whose predecessors had implemented a radical, un-democratic amalgamation several years before. Even more spectacular is the case of Moldova, where the one-shot de-amalgamation was implemented under the Communist Party Prime Minister, Vitalie Pirlog. Similarly, in Poland, the largest number of splits was approved during the term when the post-communist Social Democratic Party was the stronger partner of the governing coalition (ruling in coalition with the peasants' party PSL, the natural supporters of small rural municipalities). The case of the Czech Republic is a bit more complicated, since a hardening of the rules was introduced there under two social-democratic (but not directly post-communist) party prime ministers - Miloš Zeman and Vladimir Špidla. The case of Croatia is not very easy to interpret either. On the one hand, most splits were allowed under the centre-right HDZ government but, at the same time, it was the same party which introduced tighter conditions for secessions in 1997 and 2006 (Skarica 2021, in the same issue). The only clear exception to the rule, and the only case supporting the original hypothesis, is provided by Slovenia, where the more demanding rules for secessions were introduced in 2010 by the coalition of post-communist Social Democratic Renewal and DESUS (Democratic Party of Pensioners of Slovenia) and, as demonstrated by Baćlija and Lavtar (2021, in this issue), several cases of splits were supported by right-wing MP's. Anyway, the conclusion is that the pro- or anti-secession central level policies in Central and Eastern Europe do not have a clear political colour. Or, if we try to find any rule, in most cases (except for Slovenia and perhaps the Czech Republic) the parties which tried to limit opportunities for territorial fragmentation, were recruited from the centre and right-wing parties, rather than from left-wing and postcommunist groups, as we originally expected in our hypothesis.

Local factors of municipal secessions

Erlingsson (2005) mentions three possible drivers of secession initiatives in his model: economic, cultural (which in our formulation may to a large extent be identified with local identity) and political push, and our discussion will follow this scheme. Those drivers are often interlinked and hard to separate in practice but, analytically, distinguishing them helps to understand the forces behind the split initiatives.

\section{Economic factors}

Economic push may have two major forms:

1. The first form is related to the secession of the rich. Both Erlingsson (2005) and Brink (2004) argue that the richer part of a municipality may be inclined to secede from the less affluent remainder, even when there is a very strong fiscal equalization mechanism in place. Brink (2004) argues that, even if the overall level of municipal affluence is equalized, the richer part may have an incentive to separate its budget, since the internal budget allocation of a larger municipality can force it to contribute towards the development of infrastructure and the provision of services in the less affluent part of the jurisdiction. Brink (2004) supports her theoretical considerations with empirical analysis of Swedish cases, documenting that the more affluent parts of municipalities were more inclined to support secession initiatives in local referenda. However, Erlingsson (2005) suggests that the highest likelihood of a secession initiative from the richer part is in cases where the difference of affluence is not very big. Otherwise, secession is unlikely, since it would be delegitimized on the ground of excessive spatial inequalities, which are not accepted in (Nordic) political culture.

The argument presented above is even more likely to produce an incentive in the environment of Central and Eastern Europe. The first reason is that approval for inequalities is much larger than in Scandinavia; so even the larger difference of affluence would not de-legitimize the initiative. The second reason is that fiscal equalization in most countries in the region is much less radical than in Scandinavia; so, the pay-off of the secession, as measured by the potential financial gains, is higher. And these assumptions are indeed confirmed by empirical observations. In Poland, in 10 out of 15 cases of splits of municipalities after 1995 , the secession led to the separation of the richer part of the local government from the poorer (see also Łukomska 2021, in the same issue). In six of those cases the difference in affluence was over $10 \%$ of the local tax base, and in three cases it was over $25 \%$. Similarly, Dobos (2021, in the same issue) reports several cases of "secessions of the rich" in Hungary.

Further support for this hypothesis has been found in analysis of secession referenda held in Quebec in 2004 (Lapointe 2018). According to that study, rich towns showed greater support for secession. At the same time, the author has discovered some degree of cooperation in the provision of local public goods after the secession, which suggests that the reason for the split was not only due to differences in the preferences of local communities.

2. The second type of economic argument is related to a sense of being used (exploited) or colonized by the other part of the municipality. Of course, this feeling of marginalization may be combined with differences in affluence as described in the first type of economic factors. However, in the case of feeling marginalized, the objective indicators are not so important as the subjective feeling of disregard for the needs of part of municipality. The issue is related to the divergent interests of individual neighbourhoods within the city or villages in larger rural local government areas, due to (spatial and socio-economic) heterogeneity in the local community. Several factors may strengthen the likelihood of such centrifugal forces. They may be especially high if the "different part" of the municipality is much smaller than the rest of the local government unit. A situation likes this strengthens the feeling of being marginalized, since the political representation of the potential secessionists on the local government council is too small to defend its interests 
effectively. This feeling may also occur more often in peripheral parts (in geographical terms) of the municipality. In such a case the argument of poor physical access (proximity) to delivered services strengthens further the feeling of marginalization and raises expectations of improvement after a potential secession.

The issue discussed here may be also related to the question of effectiveness and efficiency. Whether social heterogeneity of the local government unit supports efficiency of service provision is a controversial issue. According to some authors homogeneity increases managerial effectiveness (Ostrom et al 1961). The theory goes that small jurisdictions are more homogenous and therefore can offer policies that better match their citizens' preferences. In addition, small bureaucracies allow for less distortion of citizen preferences (Hansen 2015). But some authors argue that heterogeneity may lead to more efficient service provision (Hansen 2015). However, what is most important for our discussion is that sometimes part of the municipality has a strong subjective feeling of being different from the rest of the local jurisdiction.

Earlier studies in Sweden (Gustafsson 2005) suggest that the sense of being exploited may appear in a local government unit with no "natural centre" (no town which is clearly larger than any other settlement in the municipality). But it may also be characteristic for a situation where one town dominates the surrounding rural areas, or where a peripherally-located district of a larger city feels abandoned by the town hall which concentrates on taking care of the city centre. Finally, the opposite situation is also possible: the central town feels exploited by the more numerous surrounding villages forming a "pro-rural coalition" in the local council (see the case of the split of Stoczek Łukowski in 1998 in Poland, described in Swianiewicz et al. 2018).

The expert survey of countries with cases of municipal splits suggests that the reason described in the two paragraphs above seems to be the most powerful argument in the discourse on recent municipal secessions. It was mentioned as the single, most powerful argument in four out of the nine countries covered by the survey (Bulgaria, Hungary, Poland and Slovakia), and as "very important" in two others (Czech Republic and Romania) Only in three other countries (Croatia, Lithuania and Slovenia) was it treated as a factor of moderate or low importance for the actual splits. An interesting example of a split process that was driven by a feeling of marginalization is provided in the Czech response to our expert survey; at least two split initiatives resulted from the municipality deciding to close the local village school. Frequently, the presence of a school in the village is not only an issue of physical access to a vital public service, but also an issue of local community identity, which is discussed in more detail in the following section.

\section{Local identity/cultural factors}

The cultural push for secession may be related to a general conviction that "the borders were incorrectly drawn". It may be related to drawing borders which cut through historically important, culturally uniform areas, or which unite two parts of separate historical regions. The Swedish amalgamation reform was based on Christaller's central place theory (Erlingsson 2005) which tries to identify the "natural" urban centre and its surrounding region ${ }^{5}$. However, in some cases, where there were two potential centres of similar size and economic importance, this logic did not work. In such cases the authors of the reform played the role of "social engineers", artificially selecting which would be the capital of the new, amalgamated local government. A situation like this could become a breeding ground for further secession initiatives.

${ }^{5}$ Referring to Christaller's theory may be also interpreted as building administrative division around natural, economic micro-regions, but it can be argued that the reflection of social ties and local identity are equally important.
The specific variant of this type of "cultural push" is rooted in the memory of having one's own, autonomous, local government in previous years. This is important, especially if the earlier amalgamation was implemented in a compulsory, top-down manner and has been perceived as coercion by the local community. The "drive for secession" may be particularly strong if the town (village) seeking secession is an old, historical settlement which still remembers its "former glory days" 6 .

This type of secession, being a reaction against forced amalgamation implemented under the communist regime, was the most common form of split in the early stages of political transition (i.e., in the early years of the 1990s) in Central and Eastern Europe (see section 1 of this article).

However, the focus of this article is more on contemporary cases of splits. And there is evidence that more recently also, the memory of having one's own local government unit in the past might be an important element of the discourse. Analysis of Dobos (2021, in the same issue) suggests that 17 out of 29 Hungarian municipal splits after 1999 can be identified with the creation of new municipalities, which had been separate local government units a few decades ago. In Poland, more than half of the splits which occurred after 1995, led to the establishment of new local jurisdictions with a tradition of separate local government dating back to 1970. Similar reasons are also mentioned in the Czech, Romanian and Slovak articles in this issue.

Another aspect of the cultural or social push for secession is related to the argument of the proximity between citizens and their representatives. This proximity can be understood in both a literal (geographical) and sociological sense. It might be especially important in the secession of relatively large municipalities (both in terms of population and physical size). No wonder that this argument was raised as the single most important factor in two of the countries with the largest municipal units covered by our survey: Bulgaria and Lithuania. The most recent secession in Bulgaria - of Sarnitsa (4,000 population) from the municipality of Velingrad $(34,000$ population after the split) is a good illustration of the issue. The distance between the two municipal centres is well over 40 kilometres (over 1 hour's driving time) and in the early years of the 21st century public transport connections were available only twice a week. Secession could have been motivated, among other things, by the desire to improve the physical access of citizens to town hall and administrative services (discussed already in this article in the section on economic drivers of the splits).

The case of Sarnitsa is also an example of one more factor which may push towards the split of a part of the municipality; namely national and/or religious identity of part of the population. In this particular case, part of the municipality was inhabited by Muslims, who felt different (separate) from the rest of the local community. National and/or religious heterogeneity may be a specific cultural factor that increases the likelihood of the secession initiative.

This type of argument is supported by the quantitative analysis of Lapointe (2018) studying secession referenda in Quebec. In the earlier part of this text, we mentioned his results related to higher support for secessions in richer towns. Another important factor is language diversity within the local community. Moreover:

differences in language composition alter the effect of income differences. More specifically, the effect of income differences is significantly larger when language differences

${ }^{6}$ Compare the case of the currently small village of Jaśliska on the Polish-Slovak border, which used to be an important centre of trade on a major route from Hungary in the late medieval period and during the following centuries. Jaśliska split from the larger municipality of Dukla in 2010 and, so far, it has been the most recent case of municipal secession in Poland. 
are larger. Put differently, the decision to secede from a merger is affected to some degree by out-group aversion (...) Secession may give voters the opportunity to create a more homogeneous jurisdiction in which to provide local public goods. In addition, I show that the probability to secede is lower when voters expect a tax increase following the re-constitution of the old town. However, even among towns that did secede, taxes were, on average, expected to increase. In other words, voters are actually willing to pay to avoid being merged with towns of different average socioeconomic characteristics. p. 230

This last observation suggests that demonstrating the negative economic effects of the secession might not be sufficient to discourage the split, if cultural factors strengthen the willingness to "divorce".

\section{Political factors}

The third factor - political push - belongs more to the group which concentrates on the behaviour of actors rather than on the environment in which the secession takes place, although the distinction is not very sharp in this respect, since actors usually exploit opportunities created by the environment.

The main actors in the local policy arena may be roughly divided into the following groups:

(a) politicians (e.g., councillors, recent candidates to the council, village leaders) from the part of the municipality which launches the initiative, or from the municipal centre which wants to be "Bob the bully",

(b) top politicians (mayor, councillors) of the existing municipality facing the split,

(c) local community both from the part of the municipality which initiates the "divorce" as well as from the part of the municipality to be abandoned.

(d) central level politicians (e.g., important members of parliament, government officials) who may originate from, or have their constituency in the municipality, or who for other reasons may be interested in the secession initiatives and may therefore play the role of Godfather to the secessions, or supports the existing status-quo.

As regards the behaviour of local politicians, Erlingsson (2015) notices that secession might work in favour of a particular political party. Typically, it might be supported by an opposition party, who is weaker (than the ruling party) at the level of the whole municipality, but who may be strong in the particular part which is looking to secede. Usually, in such a situation, the ruling party will oppose the split. But in the case of a weak majority for the ruling group, secession of the part with strong opposition may be supported by the existing local government in order to secure a clearer majority in the remaining part of the municipality.

In the case of Central and Eastern Europe, this partisan logic may be less important, since political parties play a lesser role in local politics than in Western Europe. This may be especially true in Poland, which has the lowest party significance index in Europe (see Egner et al 2018) and where more than 70\% of municipal councillors and mayors declare to be independent. The same is true in the case of very small local governments in the Czech Republic, Slovakia or Hungary (Soos 2005; Swianiewicz \& Mielczarek 2005). But even if there are no political parties involved, the same logic may direct the attitudes and behaviour of local political groups competing for local political power. Such small groups of local political elites often have their base in the smaller parts of municipality (individual villages).

The next important factor is the attitude of the local community from the part of the municipality which is likely to secede. To what extent is this an issue that attracts the attention only of political elites and to what extent is a there wide, in-depth support from regular citizens? The attitude of the residents of the part to be abandoned may be also of some significance. If they do not care about the split, the secession initiative will be more likely to materialize and succeed than in the case where they are afraid of the results of the reform and try to oppose it. The latter situation is more likely if the part to secede is more affluent and the boundary change may significantly worsen the capacity of the local government to invest in public infrastructure and to deliver high-quality, local services. The attitude of the local community may influence both the decisions of local politicians who are going to express their will and of central government who (in some institutional settings) has to accept the change.

Last but not least, accepting the attitude of central government together with institutional rules on boundary changes are important conditions, or even pre-conditions for success. That, often decisive, factor has been discussed already in section 2.1. of this paper. If central policy strongly opposes any territorial fragmentation, the secession initiative may remain dormant as long as favourable circumstances do not arise, since the potential leaders see no reason to initiate a process which is likely to fail eventually. But central level politics may also more indirectly interfere in the local political arena. The Polish and Croatian examples at least suggest that finding an influential central level politician to be "patron of the split" may be an effective strategy for the initiators (Swianiewicz et al 2018; Skarica 2021, the same issue), significantly increasing the chances of success.

\section{About this issue}

The articles in this issue discuss cases of splits in seven different countries of Central and Eastern Europe, referring to the model presented in the previous section.

Jakub Lysek discusses municipal secessions in the Czech Republic, which is one of the most territorially fragmented systems in Europe. In the first years after the Velvet Revolution (1990) until the end of $20^{\text {th }}$ century, secessions were usually driven by historical memory of being a separate municipality. Yet, after 2000, (when the formal rules for splits were tightened), splits were driven more by economic factors, be they objective underinvestment or perceived grievances that the mother municipality did not take care of its periphery. In most cases, the split municipality was geographically detached from its mother municipality (in rural areas). In some cases, the process concerned parts of larger cities, which had formerly been separate villages annexed as part of the urban area and with the subjective feeling of being neglected by the city's policies.

The very similar case of Slovakia is discussed in the paper by Peter Spáč. Here also, the splits were a reaction to compulsory amalgamations some years earlier and began as a widespread process almost immediately after the fall of the communist regime. More than two thirds of all the splits took a place in 1990. But in the following years, municipal secessions were still relatively frequent (a few every year), before they stopped after the introduction in 2002 of much stiffer conditions for splits. According to Spáč, the main factors behind the splits in Slovakia were related to identity/cultural issues, while economic factors were less importance.

Gabor Dobos presents his analysis of the Hungarian case against the wider background of the clash between the general perception of excessive territorial fragmentation of the local government system and the lack of political consensus to conduct any territorial reform. In spite of that perception, for a long time, municipal splits were frequent, so the level of territorial fragmentation has been gradually deepening. The situation has changed only recently, after the 2010 reform, which has 
made secessions more difficult and which introduced elements of "hidden, informal amalgamation", e.g., enforcing the joint provision of some administrative services by small municipalities.

Irena Baćlija and Robert Lavtar describe the case of Slovenia, where the first map of post-Yugoslav municipalities was drawn on the basis of a set of local referenda. The next waves of secessions were often reproducing the $19^{\text {th }}$ century borders of municipalities, which later became sub-municipal units. The 2010 amendment to the law brought tougher criteria for secession initiatives, with strict application of a minimal population threshold of 5,000 and shortening the list of actors allowed to initiate the split process. The reasons for splits are complex. The "identity factor" very often played a role. In many cases the initiators of the split successfully ran for election in the new municipalities, which may be classified as political motivation. However, the economic reason of the "secession of the rich" was found in no more than two of several dozen cases. It is important to note that the Slovenian financial system has been providing some (unintentional) financial incentives for the separation of small municipalities.

The case of Croatia, presented by Mihovil Skarica, is an example of very open rules on secessions, in which there are no clear thresholds or criteria for newly-established municipalities, so much is left to the discretion of central level politicians. In such a situation it is not surprising that most successful secession initiatives occurred in areas with strong support for the current majority party in central government; - these secessions were able to find an influential promoter at the central level more easily.

The case of Romania, discussed by Cristina Stanuş, in contrast to all the other countries researched in this issue, is an example of the active, facilitating role of central government in the process of municipal fragmentation. Central government policy opened a "window of opportunity" for several frozen secession initiatives, but the pace of fragmentation dramatically decreased when the widow was shut again.

The last case discussed in this issue is that of Poland. Julita Łukomska shows that it is significantly different from four of the other cases. Central government policies have never been supportive of splits nor have they allowed them automatically after meeting some (not very challenging) criteria. Consequently, the number of splits in Poland has been significantly lower than in any of other discussed countries. Finally, the level of territorial fragmentation in Poland is significantly below that of the other countries discussed; none of the divided municipalities was smaller than a population of 6,000 and none of the newly-created municipalities had a population of less than 1,500. However, Łukomska demonstrates that, in Poland's case, cultural or identity factors were also the most powerful impetus.

This issue provides just a step in filling the gaps in our knowledge on the strongly under-researched phenomenon of municipal splits. There is still a need for more in-depth studies of both the political processes which lead to successful splits (and which could contribute to further development of the model presented in this paper) as well as the practical outcomes of municipal secessions in terms of capacity and the costs of local public services' delivery as well as the functioning of local democracy. Collection of a full data set on split initiatives would allow us to perform such deeper analysis and would provide a more rigorous test of the model presented in figure 3, e.g., based on QCA (Qualitative Comparative Analysis). The result of such a test might be an understanding of which conditions are sufficient and which are necessary in order for a split initiative actually to be implemented.

\section{Acknowledgment}

The paper is based on results of the "Territorial reforms in Europe - comparative perspective" research project. The project has been funded by Narodowe Centrum Nauki (National Science Centre) in Poland, grant number 2017/26/M/HS5/00152

ORCID

Paweł Swianiewicz (1) https://orcid.org/0000-0002-1890-6738

\section{References}

Bačlija, I \& Lavtar, R 2021, 'Factors contributing to the municipa splits in Slovenia', Miscellanea Geographica - Regional Studies on Development, vol. 25, no. 1, pp. 54-61.

Baldersheim, H \& Rose, L 2010, Territorial choice: The politics of boundaries and borders, Palgrave-Macmillan, London.

Brink, A 2004. 'The break-up of municipalities: Voting behavior in local referenda', Economics of Governance, vol. 5(2), pp. 119-135.

Dobos, G 2021. 'Municipal splits and hidden amalgamations in Hungary', Miscellanea Geographica - Regional Studies on Development, vol. 25, no. 1, pp. 37-45.

Dollery, B, Kortt, M \& Grant, B 2011, 'A normative model for local government de-amalgamation in Australia', Australian Journal of Political Science, vol. 46(4), pp. 601-615.

Drew, J \& Dollery, B 2014, 'Separation anxiety: an empirical evaluation of the Australian Sunshine Coast Regional Council de-amalgamation', Public Money \& Management, vol. 34(3), pp. 213-220.

Drew, J, Razin, E \& Andrews, R 2019, 'Rhetoric in municipal amalgamations: a comparative analysis', Local Government Studies, vol. 45(5), pp. 748-767.

Ebinger, F, Kuhlmann, S \& Bogumil, J 2019, 'Territorial reforms in Europe: effects on administrative performance and democratic participation', Local Government Studies, vol. 45(1), pp. 1-23.
Egner, B, Gendźwiłł, A, Pleschbereger, W \& Swianiewicz, P 2018, 'Mayors and Political Parties' in Political leaders and changing local democracy: the European Mayor, eds $\mathrm{H}$ Heinelt, A Magnier, M Cabria \& H Reynaert, PalgraveMacmillan, London, pp. 327-358.

Erlingsson, GO 2005. 'Modelling secessions from municipalities', Scandinavian Political Studies, vol. 28(2), pp. 141-159.

Erlingsson, G, Ödalen, J \& Wångmar, E 2015, 'Understanding large-scale institutional change: Social conflicts and the politics of Swedish municipal amalgamations, 1952-1974', Scandinavian Journal of History, vol. 40(2), pp. 195-214.

Fox, WF \& Gurley, T 2006, 'Will consolidation improve subnational governments?', Policy Research Working Paper, vol. 3913, The World Bank, Washington.

Gendźwiłł, A, Kurniewicz, A \& Swianiewicz, P 2020, 'The impact of municipal territorial reforms on economic performance of local governments: systematic review of quasi-experimental studies', Space and Polity. Available from: <https://www. tandfonline.com/doi/full/10.1080/13562576.2020.1747420>. [20 April 2020].

Hansen, SW 2015, 'The democratic costs of size: how increasing size affects citizen satisfaction with local government', Political Studies, vol. 63, pp. 373-389.

Illner, M 2010, 'Top-down or bottom up? Coping with territorial fragmentation in the Czech Republic' in Territorial choice: 
The politics of boundaries and borders, eds $\mathrm{H}$ Baldersheim \& L Rose, Palgrave-Macmillan, London, pp. 214-233.

Ladner, A, Keuffler, N, Baldersheim, H, Hlepas, N, Swianiewicz, P, Steyvers, K \& Navarro, C 2019, Patterns of local autonomy in Europe, Macmillan, London.

Lapointe, S 2018, 'Love thy neighbor? The effect of income and language differences on votes for municipal secessions', Regional Science and Urban Economics, vol. 70, pp. 229245.

Lima, RC, de Andradem Neto, R \& da Mota Sileira 2018, 'Secession of municipalities and economies of scale: evidence from Brazil', Journal of Regional Science, vol. 58, pp. $159-180$.

Łukomska, J 2021, 'Striving for a restitution of the former splendour? Reasons for municipal splits in Poland', Miscellanea Geographica - Regional Studies on Development, vol. 25, no. 1, pp. 71-81.

Maisonobe M, Grossetti M, Milard B, Jégou L \& Eckert D 2017, 'The global geography of scientific visibility: a deconcentration process (1999-2011)', Scientometrics, vol. 113(1), pp. 479-493.

Marcou, G 1993. 'New tendencies of Local Government Development in Europe' in Local Government in the New Europe, ed. R Bennett, Belhaven Press, London, pp. 51-66.

McDonnell, J 2019, 'Municipality size, political efficacy and political participation: a systematic review', Local Government Studies, vol. 46(3), pp. 331-350.

Musilová, K \& Heřmánek, J 2015, 'Factors of Voluntary Mergers of Municipalities: a case study of the Czech Republic', Slovak Journal of Political Sciences, vol. 15(4), pp. 294-318.

Ostrom, V, Tiebout, C \& Warren, R 1961, 'The organization of government in metropolitan areas: A theoretical inquiry', American Political Science Review, vol. 55(4), pp. 831-42.

Skarica, M 2021, 'The process of local government fragmentation in Croatia: from a bong bang to a status quo', Miscellanea Geographica - Regional Studies on Development, vol. 25, no. 1, pp. 46-53.

Soos, G 2006, Local party institutionalization in Hungary, Ph.D. dissertation, Central European University, Budapest.

Stanuş, C 2021, 'Territorial fragmentation in post-communist Romania: the not so curious case of a de-amalgamation reform', Miscellanea Geographica - Regional Studies on Development, vol. 25, no. 1, pp. 62-70.

Swianiewicz, P 2010, Territorial reforms in Europe, LGI-Open Society Institute, Budapest.

Swianiewicz, P 2018, 'If territorial fragmentation is a problem, is amalgamation a solution? - ten years later', Local Government Studies, vol. 44(1), pp. 1-10.

Swianiewicz, P, Łukomska, J 2019, 'Is small beautiful? The quasi-experimental analysis of the impact of territorial fragmentation on costs in Polish local governments', Urban Affairs Review, vol. 55(3), pp. 832-855.

Swianiewicz, P, Gendźwiłł, A \& Łukomska, J 2018, 'Inicjatorzy i opuszczeni: demokracja lokalna po gminnych rozwodach' [The initiators and the abandoned: local democracy after municipal "divorces"], Prace Geograficzne, vol. 154, pp. 7-33.

Swianiewicz, P \& Mielczarek, A 2005, 'Parties and political culture in Central and Eastern European Local Governments' in Faces of Local Democracy: Comparative Papers from Central and Eastern Europe, eds G Soos \& V Zentai, Open Society Institute, Budapest, pp. 13-78.

Tanguay, GA, Wihry, DF 2008, 'Voters' preferences regarding municipal consolidation: evidence from the Quebec demerger referenda', Journal of Urban Affairs, vol. 30(3), pp. 325-345.

Tavares, AF 2018, 'Municipal amalgamations and their effects:
A literature review', Miscellanea Geographica - Regional Studies on Development, vol. 22(1), pp. 5-15. 